\title{
Multiple Use of Surface Water Resources and Bacteria Colonization of Water Bodies - Case (II) Ariam River and Other Tributaries in Ezinihite Mbaise
}

\author{
Ibezue Victoria C (Ph.D) \\ Department of Geology, Faculty of \\ Physical Sciences, \\ COO, University Uli, P.M.B. 02, \\ Uli, Nigeria
}

\author{
Ndukwe John O \\ Department of URP, Faculty of \\ Environmental Sciences, COO, \\ University Uli, P.M.B. 02, Uli, \\ Nigeria
}

\author{
Nwabineli Emma O (Ph.D) \\ ${ }^{2}$ Department of Ceramics and Glass, \\ Akanu Ibiam Federal Polytechic \\ Unwana, Ebonyi, State, Nigeria.
}

\begin{abstract}
Water samples collected along the water courses of surface water sources of domestic water supply in Ezinihite Mbaise were analyzed for bacterial species inventory and total viable count (TVC) using the multiple test tube technique and colony counters. The surface waters covered include Ariam River and other tributaries that constitute the bulk of surface water resources in the area. Eight species of bacteria including E-coli, staphylococcus aureus, salmonella, and fecal streptococci among others were identified. Total viable counts gave alarming growth levels when compared o the standards as set by the world health organization (WHO). The microbial population explosion in the river is attributable to the multiple activities within and around the river also the uses including wash off from abattoirs carrying abattoir wastes directly into the river, domestic wastes dumped along the recharge path, others include in stream fermentation of food stuff and general laundry point for any for clothes, automobiles. All these make sufficiently available to enhance microbial growth. Surface water use should be monitored to ensure sustainability and proper management of watershed will control this trend of colonization of public water supply sources and in turn control the trends in water borne infections.

Keywords: tributaries, bacteria colonization, species inventory, total viable counts, surface water and fermentation.
\end{abstract}




\section{Introduction}

The colonization of water by organisms depends on the physical and chemical state of the water [2]. Disease causing organisms enter water supplies via human wastes and sewage [5]. One of the major challenges facing environmental managers, hydrologists, water resource analysts and the allied professionals in Nigeria today is the problem of surface water pollution. And rapid urbanization, domestic and industrial activities constitute the sources of pollutants to urban and rural rivers. Surface water supplies vary in quality relative to the seasons, climatic conditions and uses [3], [6] and [4]. The area of study is drained by a major river - Ariam and three streams as its tributaries. These surface water sources are subjected to multiple uses without monitoring, as though they constitute a center for all human activities in the community; from what may be termed as general laundry (for motor bikes, fermented starches, clothes etc), through agricultural food processing, domestic uses, recreational for children, gravel and sand mining, navigation, fishing and it plays host to waste dumps including wash offs from agricultural lands. This wide range of unmonitored uses places the quality of the surface waters in the area in doubt, hence this work tried to estimate the bacteria load in the water supply sources in Ezinihite Mbaise as to advice on management options.

\section{Procedure for Data Collection}

In accord with the standard procedure for water and wastewater sampling of American Public Health Association [1] grab samples were collected from ten (10) locations across the river Ariam water course. The samples were subjected to series of analytical processes; from serial dilution, plating, incubation, inoculation and counting.

\section{Incubation}

It is done to test for species inventory, the water samples were incubated in Mac Conkey broth medium at $37^{\circ} \mathrm{C}$ and $45^{\circ} \mathrm{C}$ for 48 hours using the multi test-tube technique. The test revealed the presence of nine species of bacteria including E-coli, staphylococcus aureus, salmonella and shigella, yeast and mould, proteus mirabilis, Klebsiella pneumonia, pseudomonas aeuriginosa and fecal streptococci. Bacteria was presumed present with gas bubbles on inverted tubes indicating the presence of E-coli, thermo tolerant coliform spp on Petri dishes, acid $\mathrm{pH}$ change confirms the presence of Streptococcus Bacilli and translucent agar plates for Salmonella Typhi. Aerobic incubation in Salmonella Agar at $35^{\circ} \mathrm{C}$ for 18 -24hours showed colourless and translucent appearance that did ferment lactose nor produce $\mathrm{H}_{2} \mathrm{~S}$ which is indicative of Shigella and some Salmonella species colonies. Translucent with a black center and producing $\mathrm{H}_{2} \mathrm{~S}$ 
International Journal of Computer Applications Technology and Research

Volume 7-Issue 06, 231-240, 2018, ISSN:-2319-8656

indicates the presence of Proteus Mirabilis and most Salmonella spp. Incubation in Cled Agar: yellow opaque colonies indicates presence of E-coli; extremely mucoid colonies varying in colour from yellow to whitish blue indicates Klebsiella spp; yellow to green colonies indicates Pseudomonas Aeuriginosa; yellow colonies indicates the presence of streptococci faecalis whereas deep yellow colonies presents staphylococcus aureus spp.

\section{Relevance of the Study}

This work is recommended for both scholars in water resources and environmental pollution. The innocence with which the users carry out their daily activities within and around water bodies tells a lot about their level of ignorance of the severity of the effects of the said activities. Coupled with the fact that, they are victims of their own doing as it is them that use the water for drinking and other domestic purposes. The various uses predisposes them to myriads of diseases from the organisms identified. Therefore, this paper if made available to public by publishing, will serve to educate the members of the public of the implication of wrong approaches to public utilities. To think that water consumption accounts for many diseases depending on the source.

\section{Biomass Estimation}

The heterotrophic plate count was used to determine the total viable count of the individual bacterial species identified. On serial dilution, $2 \mathrm{ml}$ of water sample was adapted in $10 \mathrm{ml}$ of molten yeast agar extract on flat dish at $45^{\circ} \mathrm{C}$. The culture was allowed to cool down and the plates inoculated at different temperature and time ranges (one at $22^{\circ} \mathrm{Cfor} 72$ hours and the other at $37^{\circ} \mathrm{C}$ for 24 hours). The colonies that appeared were counted on the microscope and the counts reflect the Total Viable Counts for the individual water borne bacteria present.

\section{Membrane Filtration}

Further step was taken as to confirm the presence of thermo- tolerant species of coli-form bacteria, so that the water sample was passed through the membrane filtration equipment and the filter incubated in Lauryl Sulphate Agar plates aerobically for 24 hours at $22^{\circ} \mathrm{C}$ and then for 14 hours at $44^{\circ} \mathrm{C}$, a yellow colony confirms coli-form present. Positive methyl red reaction (indicative of a mixed acid fermentation) and negative reaction/non citrate utilization in appropriate media can aid confirmatory tests for coli-form.

\section{Findings}

The table below shows that about eight (8) different species of bacteria were present in varying number of counts in all the samples which are collected from different locations as figure 1 below reflects. 
International Journal of Computer Applications Technology and Research

Volume 7-Issue 06, 231-240, 2018, ISSN:-2319-8656

Table 1 below reflects the result of the species inventory and the total

viable counts (TVC) for the individual species identified.

Table 1: Bacteria species inventory and the total viable counts (TVC)

\begin{tabular}{|c|c|c|c|c|c|c|c|c|}
\hline $\begin{array}{l}\text { SAMPL } \\
\text { ES }\end{array}$ & $\begin{array}{l}\text { STREPTOCO } \\
\text { CCI (FECAL) }\end{array}$ & $\begin{array}{l}\text { PROTEU } \\
\text { S } \\
\text { MIRABIL } \\
\text { IS }\end{array}$ & E COLI & $\begin{array}{l}\text { KLEBSIEL } \\
\text { LA } \\
\text { PNEUM }\end{array}$ & $\begin{array}{l}\text { SALMON } \\
\text { ELLA } \\
\text { SHIGELL } \\
\text { A }\end{array}$ & $\begin{array}{l}\text { CLOSTRIDI } \\
\text { UM }\end{array}$ & $\begin{array}{l}\text { PSEUDO } \\
\text { AERUINO } \\
\text { SA }\end{array}$ & $\begin{array}{l}\text { STAPH } \\
\text { AURE } \\
\text { US }\end{array}$ \\
\hline I & $6.3 \times 10^{7}$ & $5.2 \times 10^{7}$ & $\begin{array}{ll}8.1 & X \\
10^{7} & \end{array}$ & $2.4 \times 10^{7}$ & $5.0 \times 10^{7}$ & $1.2 \times 10^{7}$ & $6.4 \times 10^{7}$ & $\begin{array}{ll}5.2 & X \\
10^{7} & \end{array}$ \\
\hline Ii & $7.4 \times 10^{7}$ & $5.0 \times 10^{7}$ & $\begin{array}{ll}6.5 & \mathrm{X} \\
10^{7} & \end{array}$ & $2.9 \times 10^{7}$ & $2.7 \times 10^{7}$ & $1.4 \times 10^{7}$ & $5.3 \times 10^{7}$ & $\begin{array}{ll}4.1 & \mathrm{X} \\
10^{7} & \end{array}$ \\
\hline Iii & $8.3 \times 10^{7}$ & $4.1 \times 10^{7}$ & $\begin{array}{ll}8.4 & \mathrm{X} \\
10^{7} & \end{array}$ & $6.6 \times 10^{7}$ & $3.5 \times 10^{7}$ & $2.6 \times 10^{7}$ & $5.1 \times 10^{7}$ & $\begin{array}{ll}5.3 & X \\
10^{7} & \end{array}$ \\
\hline $\mathrm{Iv}$ & $5.4 \times 10^{7}$ & $4.5 \times 10^{7}$ & $\begin{array}{ll}6.5 & X \\
10^{7} & \end{array}$ & $4.3 \times 10^{7}$ & $4.7 \times 10^{7}$ & $2.3 \times 10^{7}$ & $4.5 \times 10^{7}$ & $\begin{array}{ll}6.0 & X \\
10^{7} & \end{array}$ \\
\hline V & $4.8 \times 10^{7}$ & $3.2 \times 10^{7}$ & $\begin{array}{ll}5.5 & X \\
10^{7} & \end{array}$ & $4.7 \times 10^{7}$ & $5.5 \times 10^{7}$ & $3.5 \times 10^{7}$ & $4.9 \times 10^{7}$ & $\begin{array}{ll}3.2 & X \\
10^{7} & \end{array}$ \\
\hline $\mathrm{Vi}$ & $7.0 \times 10^{7}$ & $3.6 \times 10^{7}$ & $\begin{array}{ll}6.3 & X \\
10^{7} & \end{array}$ & $5.1 \times 10^{7}$ & $7.2 \times 10^{7}$ & $4.5 \times 10^{7}$ & $5.0 \times 10^{7}$ & $\begin{array}{ll}4.7 & \mathrm{X} \\
10^{7} & \end{array}$ \\
\hline Vii & $7.2 \times 10^{7}$ & $4.4 \times 10^{7}$ & $\begin{array}{ll}6.2 & X \\
10^{7} & \end{array}$ & $6.0 \times 10^{7}$ & $6.3 \times 10^{7}$ & $3.0 \times 10^{7}$ & $5.4 \times 10^{7}$ & $\begin{array}{ll}4.5 & X \\
10^{7} & \end{array}$ \\
\hline Viii & $6.7 \times 10^{7}$ & $4.5 \times 10^{7}$ & $\begin{array}{ll}5.1 & X \\
10^{7} & \end{array}$ & $6.1 \times 10^{7}$ & $4.1 \times 10^{7}$ & $2.7 \times 10^{7}$ & $5.7 \times 10^{7}$ & $\begin{array}{ll}5.0 & X \\
10^{7} & \end{array}$ \\
\hline Ix & $5.4 \times 10^{7}$ & $5.0 \times 10^{7}$ & $\begin{array}{ll}6.0 & X \\
10^{7} & \end{array}$ & $6.5 \times 10^{7}$ & $7.7 \times 10^{7}$ & $4.8 \times 10^{7}$ & $4.3 \times 10^{7}$ & $\begin{array}{ll}7.2 & X \\
10^{7} & \end{array}$ \\
\hline $\mathrm{x}$ & $6.2 \times 10^{7}$ & $6.2 \times 10^{7}$ & $\begin{array}{ll}7.4 & X \\
10^{7} & \\
\end{array}$ & $5.5 \times 10^{7}$ & $5.8 \times 10^{7}$ & $3.3 \times 10^{7}$ & $6.2 \times 10^{7}$ & $\begin{array}{ll}6.1 & X \\
10^{7} & \\
\end{array}$ \\
\hline
\end{tabular}

Whereas figure 1 below shows the extent of colonization of the surface water sources by the bacteria species in terms of spread along the water courses. 
International Journal of Computer Applications Technology and Research

Volume 7-Issue 06, 231-240, 2018, ISSN:-2319-8656

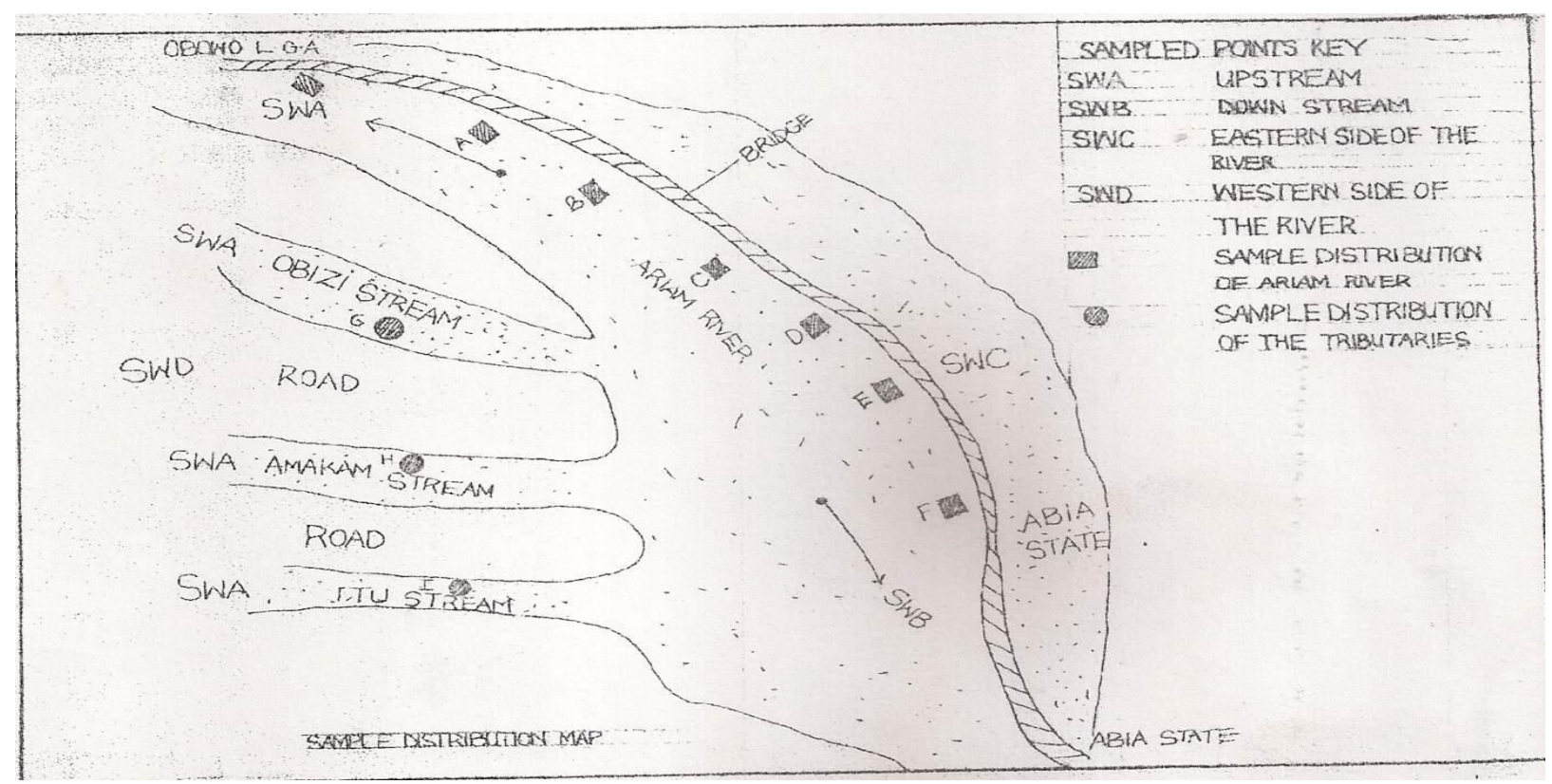

Figure 1. Map of the study area showing sample locations

Figures 2, 3 and 4 below are a graphical representation of some of the data in table which tries to compare TVC within and across samples. Observation shows that there are variations in TVC between and across samples and from location to location as well as between water bodies. The variation from place to place may be attributed to the proximity to the various point sources of these organisms, as regards the points of entrance into the water bodies from human activities going in those places. 
International Journal of Computer Applications Technology and Research

Volume 7-Issue 06, 231-240, 2018, ISSN:-2319-8656

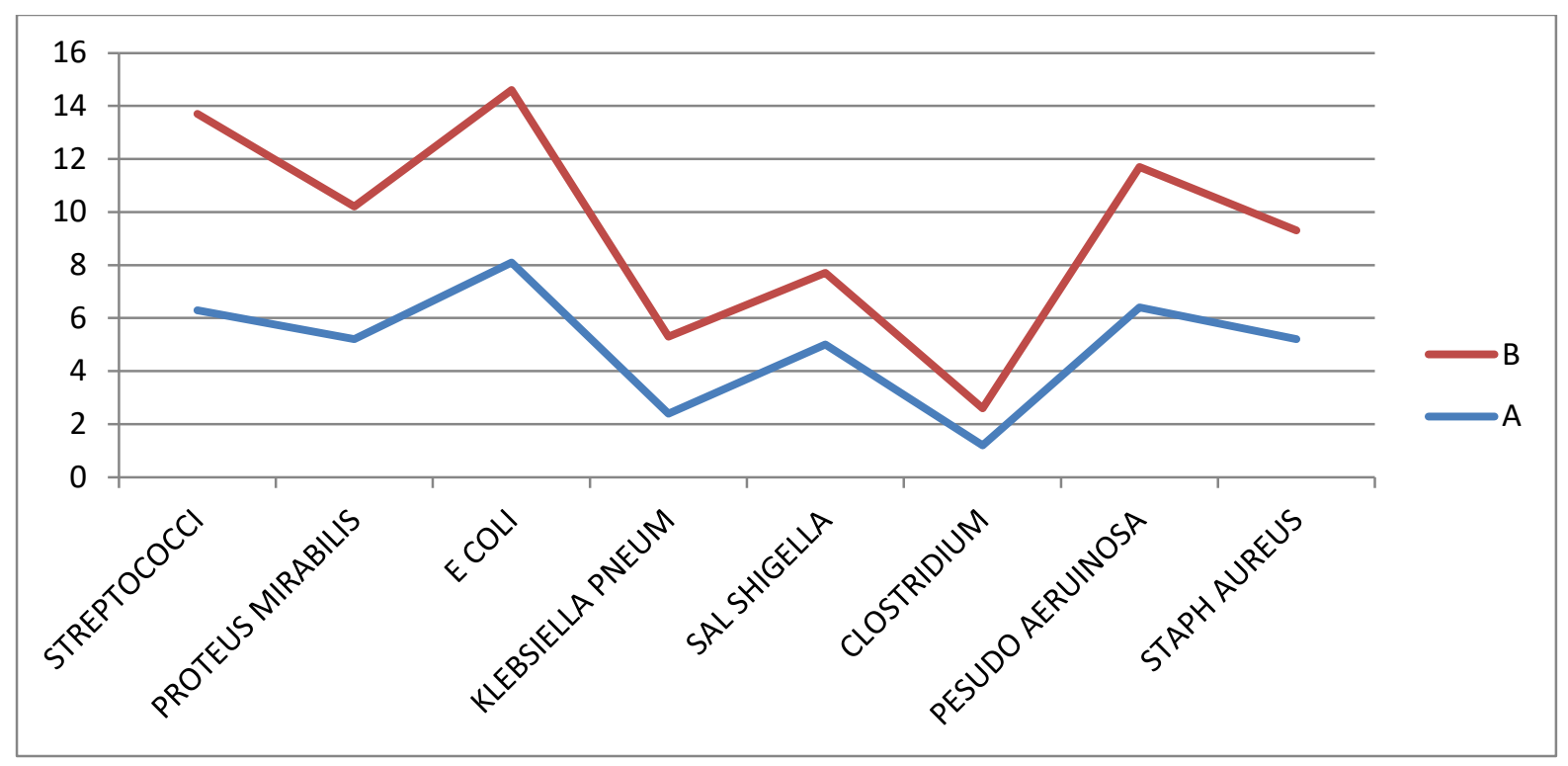

Figure 2. Graphical representation comparing results from two locations (A\&B) along river Ariam water course 
International Journal of Computer Applications Technology and Research

Volume 7-Issue 06, 231-240, 2018, ISSN:-2319-8656

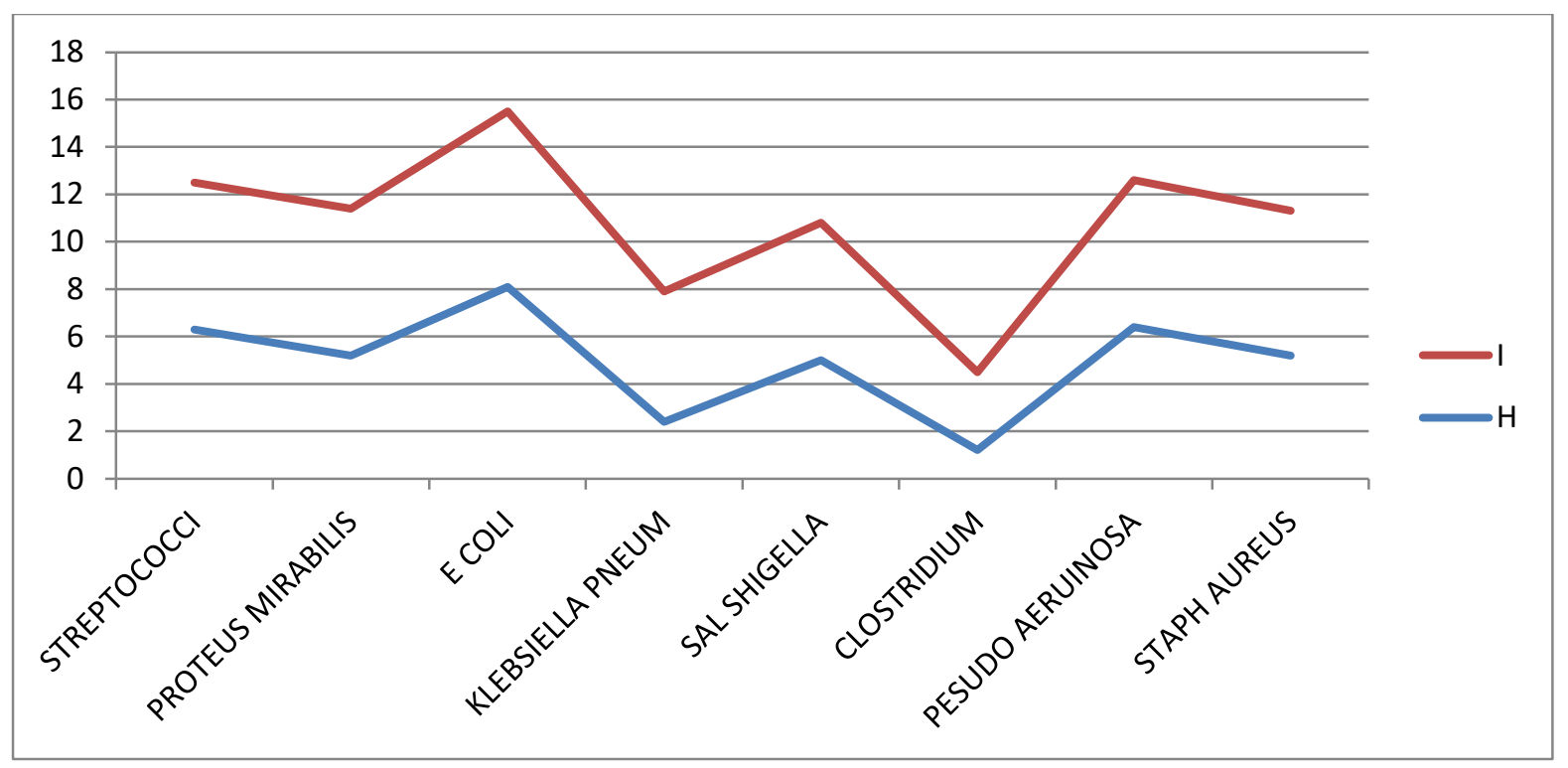

Figure 3. Graphical representation comparing results from two locations I( Itu) and H (Amakam) streams 
International Journal of Computer Applications Technology and Research

Volume 7-Issue 06, 231-240, 2018, ISSN:-2319-8656

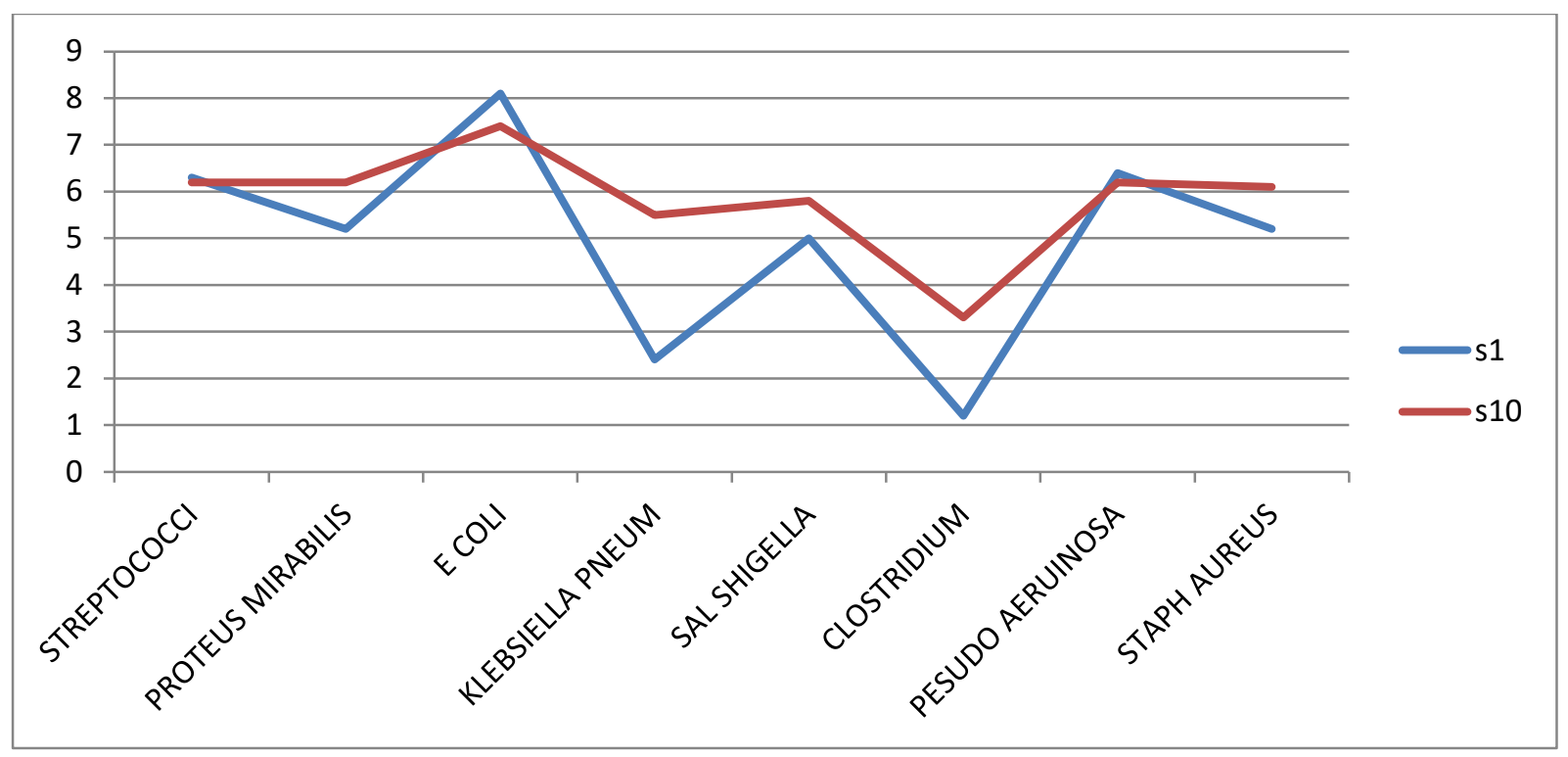

Figure 4. Graphical representation comparing results from two locations Itu stream and Ariam river

Figure 5 below is a plot of the biological water quality indicator (E-coli) and the fecal streptococci against other species of bacteria present show that the two are at all times and all places high in TVC indicating strong relationship between its occurrence and human activities. 
International Journal of Computer Applications Technology and Research

Volume 7-Issue 06, 231-240, 2018, ISSN:-2319-8656

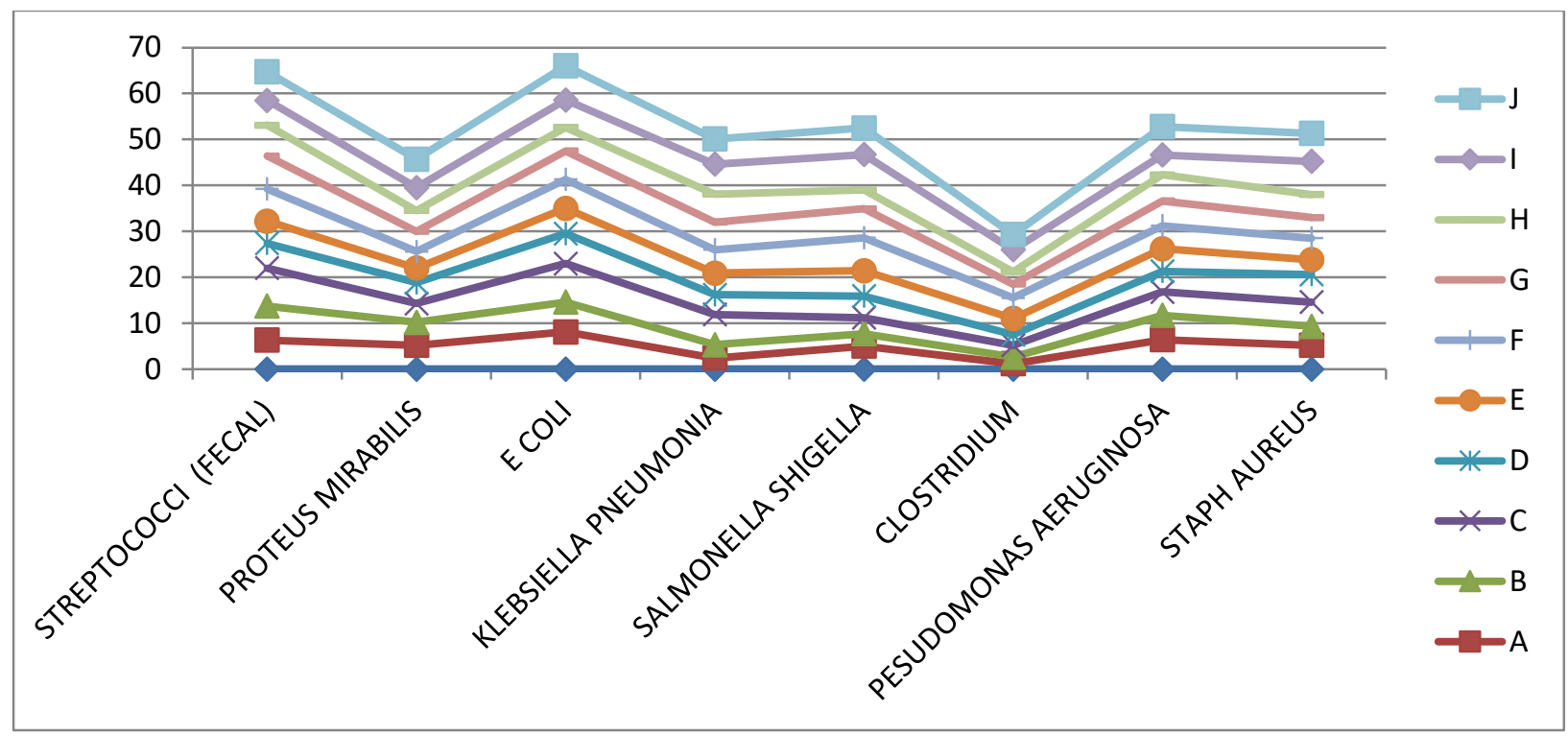

Figure 5. Graphical representation comparing TVC of individual species at various locations

\section{Implication of Findings}

The extent of colonization in terms of spread and the numerical strength of the organisms shows that the water supply source in the study area is unfit for drinking and most domestic uses as it is also evident that using such water in washing of food stuff, bathing predisposes the very user to infection. The water use pattern designate in the study area serve as a recycling process to these organisms concerning the severity of routine uses which the water body serves from drinking, through other domestic uses to playing host to human wastes (directly discharged by persons into the water or indirectly through runoff) and wastes (domestic, industrial and agricultural). 
International Journal of Computer Applications Technology and Research

Volume 7-Issue 06, 231-240, 2018, ISSN:-2319-8656

\section{Summary}

The surface water sources of water supply in the study area require massive disinfection along the length and breadth of the water bodies.

And the direct use such as washing fermented starches and other biodegradables as well as direct discharge of wastes by persons of human wastes into the surface water bodies or on the recharge area should be discouraged by community leaders. Dislodging industrial wastes into the surface water sources should be disallowed while protecting the recharge paths from agricultural land wash offs and the water bodies from any harmful activity. The surface water sources can be kept from direct use especially the upstream side and water can be pumped out and piped away from source to various locations and as the need arises. Even canals/impoundment pits can be used to extract water from the main rivers/streams to provide for other uses.

\section{References}

[1] APHA-AWWA-WPCF (1995): Standard methods for the examination of water and waste waters, $17^{\text {th }}$ Ed. American Public Health Association Washington DC.

[2] Okechukwu,G. C. (1983): "the effects of tin mining on the hydrology and water resources

[3] Onwuekwe, (2004): “ bacteriological and physicochemical characteristics of some

selected points along the River Niger" B.SC. Thesis submitted to the Department of Production Technology, Nnamdi Azikiwe University Awka

[4] Nwackukwu, Okereke and Ukpabi (1998): "Pollution level of Otamiri River, Environmental Review, Vol. 1 No.2

[5] Wagner, E. G. and Lanoix, J.N. (1959): "Water supply for rural areas and small

communities", World Health Organization, Geneva.

[6] Watts,J. (1953): Availability of water and diseases" In American Journal of Public Health, 43:728 